\title{
ESTIMATION OF SOME TRACE ELEMENTS IN HEALTHY AND DISEASED SHEEP IN QENA GOVERNORATE
}

\author{
MALK ISMAIL IBRAHIM ${ }^{1}$, ADEL ELSAYED AHMED MOHAMED ${ }^{2}$, ALSAGHER O. ALI $^{2}$ \\ and HASSAN Y.A.H. MAHMOUD ${ }^{2}$ \\ ${ }^{1}$ Department of Veterinary National Service, Qena, Egypt \\ ${ }^{2}$ Animal Medicine Department, Faculty of Veterinary Medicine, South Valley University, Qena 83523, Egypt.
}

Received: 31 December 2016; $\quad$ Accepted: 30 January 2017

\begin{abstract}
Trace elements deficiency constitutes an economic problem, can seriously threaten a large scale of the ruminant. It resulted in hemato-biochemical alterations which adversely impact animal's production. The present study was designed to investigate factors affecting animal's minerals status and evaluate correlation attributed element deficiency. This study was established on 300 sheep including lamb and adults from both sexes (male and female), animals comprising healthy and diseased sheep. Blood samples were collected for hematological and biochemical determination at winter and spring seasons of year 2015 and 2016 in Qena governorate. It could be concluded that several factors can affect trace elements deficiency like sex, age, lactation, pregnancy and healthy status of the animals. Diseased sheep which showed signs of alopecia, dehydration and anemia are suffered from serum elements deficiency like total iron, zinc, calcium, phosphorus and magnesium, besides reduction in red blood cell count and hemoglobin concentration.
\end{abstract}

Key Words: Trace elements, Sheep, Qena Governorate

\section{INTRODUCTION}

Trace elements are very important for increasing resistance to diseases in living organisms (Sahin, 1999). Moreover, it has an important role on growth, reproduction and productivity of domestic animals (Hayat et al., 2010). Mineral deficiency or imbalance observed in nearly everywhere in the world causes significant economic losses (Jones et al., 1990; Graham, 1991; Dakka and Abdel-All, 1992; Sahin, 1999). It is reported that losses caused by trace elements are important as the losses caused by infectious and parasitic diseases (Sahin, 1999).

Copper, zinc, selenium and iron are essential trace elements associated with specific and non-specific immune mechanisms (Chandra, 2003). It was known to be dietary and metabolic essential elements; They control numerous enzymatic and metabolic functions (Rink and Ibs, 2003). The relation between $\mathrm{Cu}$ and $\mathrm{Zn}$ is very much similar to that between calcium and phosphorus. A significant decrease in serum level of copper, iron, zinc, cobalt and manganese in sheep was associated with some diseased conditions induced

Corresponding author: Dr. ADEL ELSAYED AHMED MOHAMED E-mail address: adel.mohamed@vet.svu.edu.eg

Present address: Animal Medicine Department, Faculty of Veterinary Medicine, South Valley University, Qena 83523, Egypt. alopecia and deficient anemia (Ali, 2000). Data concerning factors affecting trace element deficiency and relation attributed element deficiency is still rare.

\section{MATERIALS AND METHODS}

A total of 300 random sample of sheep sera were collected from sheep belonging to faculty of veterinary medicine in Qena, slaughter house in Qeft city and from villages in Qeft city, Qena governorate. Samples were collected from apparently healthy animals and diseased animals. Healthy (control) animals were in good body score, physically and clinically healthy. Diseased animals showed signs of diarrhea, emaciation, loss of appetite, dehydration, alopecia and anemia with paleness of external mucous membrane.

Blood samples were collected from jugular vein and divided into two parts. First part of blood samples collected in heparinized tubes containing anticoagulant for hematological parameters as red blood cell count and hemoglobin concentration. Second was collected in test tubes without anticoagulant, allowed to clot at room temperature $\left(37^{\circ} \mathrm{C}\right)$ and centrifuged at $3.000 \mathrm{rpm}$ for $15 \mathrm{~min}$ to separate the serum.

Heparinized blood used for count of red blood cells (TRBCs) according to Fieldman et al. (2000). Also, 
hemoglobin concentration (Hb.) was analyzed according to Lucky, (1977).

Clear separated serum used for mineral analysis. Serum copper was evaluated using colorimetric method described by Ventura and King, (1951). Total serum iron was colorimetrically determined via method expressed by Bauer, (1984). Zinc level was estimated according to Hayakawa, (1961). Serum calcium was assessed by the techniques of Ginder and King, (1972). Phosphorus level in serum was measured using colorimetric method described by ElMerzabani et al. (1977). Magnesium level was determined using the technique delineated by Teitz, (1983).

\section{Statistical analysis}

The data was conducted using one-way analysis of variance (ANOVA), followed by post-hoc analysis (Dunnett's test) using SPSS (Statistical Package for Social Sciences) version 17 according to Borenstein et al. (1997). The data were presented in form of Mean \pm Standard Deviation. The difference was considered statistically significant when $P<0.05$.

\section{RESULTS}

\section{Red blood cell count}

The results showed insignificant changes in TRBCs count between healthy and diseased female sheep either in lamb, pregnant ewe, lactating ewe, or elder ewe Moreover, there is insignificant changes in TRBCs count of the healthy male sheep either in young and elder rams. While, TRBCs count of young rams that suffered from diseased conditions revealed significant decrease compared with elder rams. TRBCs count of male sheep of the diseased animals showed significant decrease in young and elder rams when compared with those of healthy animals $(P<0.05)$. TRBCs count of diseased elder ewe was significantly decreased when compared with control $(P<0.05)$ (Table 1).

\section{Hemoglobin concentration}

There was significant decrease in hemoglobin concentration of the lactating and elder ewe of healthy female sheep when compared with healthy lamb and pregnant ewe $(P<0.05)$. On the contrast, insignificant changes observed between hemoglobin concentrations of the diseased female sheep. Diseased lamb showed significant decrease in hemoglobin concentration when compared with healthy lamb $(P<0.05)$. Other diseased female sheep don't exhibit any changes in hemoglobin concentration when compared with healthy animals. Hemoglobin concentration of the healthy male sheep showed significant decrease in the elder rams when compared with young rams $(P<0.05)$. In case of the diseased sheep, hemoglobin concentration was insignificantly changes in the elder rams when compared with young rams. Young rams of the diseased group exhibited significant decrease in hemoglobin concentration when compared with young healthy ones $(P<0.05)$ (Table 1).

\section{Copper in serum}

Copper displayed significant decreases in its level in pregnant ewe, lactating ewe and elder ewe of healthy female sheep when compared with respective lamb $(P<0.05)$. Moreover, there was significant decrease in copper values of pregnant ewe, lactating ewe and elder ewe of diseased female sheep when compared with lamb $(P<0.05)$. Copper level of the elder rams was significantly decreased in the elder rams of healthy animals when compared with respective lamb $(P<0.05)$. While in the diseased animals, there were insignificant changes recorded between young and elder rams. Significant decrease was detected in copper level of diseased elder rams when compared with healthy animals $(P<0.05)$ (Table 2$)$.

\section{Iron in serum}

A significant decrease detected in total iron level of healthy and diseased female sheep involving pregnant, lactating and elder ewe when compared with lamb $(P<0.05)$. There were significant decreases recorded in total serum iron in the diseased female sheep either lamb, pregnant ewe, lactating ewe and elder ewe when compared with those of healthy female sheep $(P<0.05)$. Total iron showed nonsignificant decrease in elder rams of the healthy rams when compared with values of the young rams $(P<0.05)$. While, total iron in elder rams of the diseased rams revealed significant decrease when compared with values of the young rams $(P<0.05)$. Besides, significant reduction was observed in young and elder rams of diseased animals when compared with respective healthy animals (Table 2).

\section{Zinc in serum}

There was significant decrease in zinc level of healthy and diseased female sheep involving pregnant, lactating and elder ewe when compared with lamb $(P<0.05)$. Significant decrease was noticed in zinc level of diseased female sheep involving lamb, pregnant ewe, lactating ewe and elder ewe when compared with those of the healthy female sheep $(P<0.05)$. Zinc values of healthy rams showed insignificant changes between young and elder ages, while that of diseased animals, there was significant decrease in elder rams when compared with young rams $(P<0.05)$. Elder rams of the diseased animals recorded significant decrease in zinc level when compared with healthy elder rams $(P<0.05)$ (Table 2$)$.

\section{Calcium in serum}

Calcium data of healthy and diseased female sheep recorded non-significant changes in all groups, Only elder ewe of the healthy female sheep showed significant decease when compared with others $(P<0.05)$. The diseased female sheep showed 
significant decrease in calcium level of lamb, pregnant ewe and lactating ewe when compared with healthy lamb, pregnant ewe and lactating ewe $(P<0.05)$. Level of the calcium recorded significant decrease in elder rams in comparison with young rams of the healthy and diseased animals $(P<0.05)$. Also, diseased rams showed significant decrease in calcium level of young and elder rams when compared with healthy rams $(P<0.05)$ (Table 2$)$

\section{Phosphorus in serum}

Data exhibited non-significant changes in phosphorus level of the female sheep between lamb, pregnant, lactating and elder ewe in the healthy and diseased animals $(P<0.05)$. Phosphorus level was significantly decreased in the diseased pregnant and elder ewes when compared with those of the healthy animals $(P<0.05)$. Non-significant changes recorded in phosphorus level of the male sheep either young or elder sheep in the healthy animals including young and elder rams $(P<0.05)$ exhibited non-significant changes in phosphorus level of the male sheep either young or elder sheep in the diseased animals including young and elder rams $(P<0.05)$. Phosphorus level of the elder rams revealed significant decrease in diseased animals when compared with healthy elder rams $(P<0.05)$ (Table 2$)$

\section{Magnesium in serum}

Level of magnesium between lamb, pregnant, lactating and elder ewe of the healthy animals showed non-significant changes $(P<0.05)$. Also, magnesium level of the female sheep of lamb, pregnant and lactating ewe of the diseased animals showed nonsignificant changes, while, elder ewe revealed significant increase in magnesium level $(P<0.05)$. Significant changes were detected in magnesium level in diseased lamb, pregnant, lactating and elder ewe when compared with those of healthy animals.

Table 1: Total Erythrocytic Count and Hemoglobin Values in the Healthy and Diseased Sheep.

\begin{tabular}{cccccccc}
\hline & \multicolumn{2}{c}{ Pemale } & \multicolumn{2}{c}{ Male } \\
\cline { 2 - 8 } \multicolumn{2}{c}{ Statistics } & Lamb & $\begin{array}{c}\text { Pregnant } \\
\text { ewe }\end{array}$ & $\begin{array}{c}\text { Lactating } \\
\text { ewe }\end{array}$ & $\begin{array}{c}\text { Elder } \\
\text { ewe }\end{array}$ & $\begin{array}{c}\text { Young } \\
\text { rams }\end{array}$ & $\begin{array}{c}\text { Elder } \\
\text { rams }\end{array}$ \\
\hline $\begin{array}{c}\text { Total } \\
\text { Erythrocytic } \\
\text { count }(\mathbf{R B C s}) \\
\mathbf{1 0} / \mathbf{C ~} \mathbf{~ m m}\end{array}$ & control & $20.3 \pm 1.5$ & $19.6 \pm 1.5$ & $20 \pm 1.5$ & $21.3 \pm 0.5$ & $16 \pm 2.6$ & $17.3 \pm 0.5$ \\
\hline $\begin{array}{c}\text { Hemoglobin } \\
(\mathbf{H b}) \mathbf{g m} / \mathbf{d l}\end{array}$ & control & $16.3 \pm 1.2$ & $15.0 \pm 1.7$ & $10.0 * \pm 1.0$ & $11.0 * \pm 1.0$ & $13.0 \pm 2.0$ & $9.3 * \pm 1.5$ \\
\cline { 2 - 9 } & diseased & $9.3 \pm 1.5$ & $12.7 \pm 1.5$ & $9.3 \pm 1.5$ & $9.3 \pm 0.5$ & $10.3 \pm 1.1$ & $9.3 \pm 1.5$ \\
\hline
\end{tabular}

Data are presented as means $\pm \mathrm{SE}$

$* \rightarrow$ Referred to significant changes when $\mathrm{P}<0.05$.

Table 2: Copper, Iron, Zinc, Calcium, Phosphorus and Magnesium values of the healthy and diseased sheep.

\begin{tabular}{|c|c|c|c|c|c|c|c|}
\hline & \multicolumn{4}{|c|}{ Female } & \multicolumn{2}{|c|}{ Male } \\
\hline & & \multirow{2}{*}{$\begin{array}{c}\text { Lamb } \\
419.3 \pm 20\end{array}$} & \multirow{2}{*}{$\begin{array}{c}\begin{array}{c}\text { Pregnant } \\
\text { ewe }\end{array} \\
366^{*} \pm 13\end{array}$} & \multirow{2}{*}{$\begin{array}{c}\begin{array}{c}\text { Lactating } \\
\text { ewe }\end{array} \\
151 * \pm 24.5 \\
\end{array}$} & \multirow{2}{*}{$\begin{array}{c}\begin{array}{c}\text { Elder } \\
\text { ewe }\end{array} \\
127^{*} \pm 6.5 \\
\end{array}$} & \multirow{2}{*}{$\begin{array}{c}\begin{array}{c}\text { Young } \\
\text { rams }\end{array} \\
96.3 \pm 5.5\end{array}$} & \multirow{2}{*}{$\begin{array}{c}\begin{array}{c}\text { Elder } \\
\text { rams }\end{array} \\
84.3^{*} \pm 9.3 \\
\end{array}$} \\
\hline Copper & control & & & & & & \\
\hline$(\mu \mathrm{g} / \mathrm{dl})$ & diseased & $373 \pm 23.9$ & $347 * \pm 24.6$ & $140 * \pm 15.6$ & $116 * \pm 4.5$ & $89.3 \pm 9.5$ & $81.6 \pm 9.1$ \\
\hline \multirow{2}{*}{$\begin{array}{l}\text { Total serum } \\
\text { iron }(\mu \mathrm{g} / \mathrm{dl})\end{array}$} & control & $216.3 \pm 15.1$ & $148.3 * \pm 34$ & $156.0 * \pm 12.2$ & $112.3 * \pm 10.6$ & $227.3 \pm 23.5$ & $217.0 \pm 15.3$ \\
\hline & diseased & $120 \pm 10$ & $95.7 * \pm 5.8$ & $77.6^{*} \pm 9.5$ & $49.6^{*} \pm 3.1$ & $102.0 \pm 8.3$ & $65.3^{*} \pm 13.0$ \\
\hline \multirow{2}{*}{ Zinc $(\mu \mathrm{g} / \mathrm{dl})$} & Control & $329.3 \pm 26.1$ & $256.7 * \pm 30.5$ & $250.0 * \pm 48.8$ & $155.3^{*} \pm 12.9$ & $284.7 \pm 17.2$ & $275.7 \pm 15.0$ \\
\hline & Diseased & $172.7 \pm 6.1$ & $79.6^{*} \pm 10.6$ & $146.7^{*} \pm 12.2$ & $94.3 * \pm 6.6$ & $278.0 \pm 2.6$ & $168.0 * \pm 11.1$ \\
\hline \multirow{2}{*}{$\begin{array}{r}\text { Calcium } \\
(\mathrm{mg} / \mathrm{dl})\end{array}$} & control & $20.6 \pm 2.1$ & $20.7 \pm 1.5$ & $19.5 \pm 0.5$ & $15.3 * \pm 3.1$ & $21.3 \pm 2.1$ & $15.3 * \pm 1.5$ \\
\hline & diseased & $15.3 \pm 1.5$ & $15.2 \pm 1.6$ & $14.0 \pm 0.1$ & $13.3 \pm 1.5$ & $14.0 \pm 2.6$ & $9.0 * \pm 0.1$ \\
\hline \multirow{2}{*}{$\begin{array}{c}\text { Phosphorus } \\
\text { (mg/dl) }\end{array}$} & control & $7.4 \pm 1.5$ & $7.0 \pm 1.5$ & $6.0 \pm 0.7$ & $7.7 \pm 1.8$ & $5.6 \pm 0.6$ & $5.2 \pm 0.8$ \\
\hline & diseased & $7.3 \pm 2.1$ & $4.6 \pm 1.5$ & $5.5 \pm 0.1$ & $5.5 \pm 0.5$ & $5.4 \pm 0.4$ & $4.8 \pm 0.4$ \\
\hline \multirow{2}{*}{$\begin{array}{l}\text { Magnesium } \\
\text { (mg/dl) }\end{array}$} & Control & $9.8 \pm 0.9$ & $9.4 \pm 0.7$ & $9.9 \pm 0.6$ & $8.4 \pm 0.6$ & $9.7 \pm 0.6$ & $9.1 \pm 0.8$ \\
\hline & Diseased & $4.4 \pm 0.4$ & $4.5 \pm 0.5$ & $4.3 \pm 1.2$ & $5.9 * \pm 0.2$ & $6.2 \pm 0.3$ & $4.5^{*} \pm 0.5$ \\
\hline
\end{tabular}

Data are presented as means $\pm \mathrm{SE}$

$* \rightarrow$ Referred to significant changes when $\mathrm{P}<0.05$. 


\section{DISCUSSION}

Hemato-biochemical results varied in young and old sheep; also it was different in pregnant than lactating animals (Dar et al., 2014) who mentioned that there was significant influence of physiological status and seasonal variation on plasma mineral concentration of sheep. Besides, Tashi et al. (2005) stated that mineral inadequacies in livestock are often seasonal, resulting from increased demands of pregnancy, lactation or rapid growth.

Hematological findings revealed that TRBC count of the diseased elder ewe was significantly decreased when compared with healthy animals. TRBCs count of male sheep of the diseased animals showed significant decrease in young and elder rams when compared with those of healthy animals. There was significant decrease in hemoglobin concentration of diseased lamb when compared with healthy ones. Diseased young rams exhibited significant decrease in hemoglobin concentration when compared with healthy young rams. This decrease might be due to disturbance in the regular metabolism of iron as copper deficiency decreases the absorption of iron, releasing of iron from body stores and utilization in hemoglobin synthesis (McDonald et al., 1984 and Church and Pond, 1988). Abd El-Raof and Ghanem, (2006) observed that multiple trace element deficiencies particularly copper, zinc, manganese and iron caused decreases in hemoglobin concentration (Hb) and total erythrocytic count (TRBCs). Hayton et al. (1995) mentioned that erythrocyte deficiency was associated with lack of serum copper. This is known due to increase hemolysis and peroxidation of erythrocytes and thereby promotes anemia.

Biochemical analysis of serum samples of alopecic animals revealed significant decrease in copper and zinc, manganese and iron level was recorded. Similar results were obtained by Fahmy et al. (1980) who recorded a significant decrease in the levels of copper, zinc, manganese and iron in sheep with alopecia and wool eating. Moreover, Ali, (2000) reported a significant decrease of the values of serum copper, iron, zinc, cobalt and manganese in sheep showing alopecia.

Copper displayed significant decreases in its level in pregnant ewe, lactating ewe and elder ewe of healthy female sheep when compared with lamb. Significant decrease was detected in copper level of diseased elder rams when compared with healthy animals. There was significant decrease in zinc level of healthy and diseased female sheep involving pregnant, lactating and elder ewe when compared with lamb. Significant decrease was noticed in zinc level of diseased female sheep involving lamb, pregnant ewe, lactating ewe and elder ewe when compared with those of the healthy female sheep.
Elder rams of the diseased animals recorded significant decrease in zinc level when compared with healthy elder rams.

Zinc and Copper are very important for sheep health and production. Zinc is a constituent of numerous metaloenzymes and required for normal protein synthesis and metabolism (Church and Pond, 1988). Zinc deficiency may be primary due to inadequate levels in the ration or secondary as a result of the presence of a substance interfering with its absorption or metabolism, in spite of the normal diet concentration (Wikse et al., 1992).

There were significant decreases recorded in total serum iron in the diseased female sheep either lamb, pregnant ewe, lactating ewe and elder ewe when compared with those of healthy female sheep. While, total iron in elder rams of diseased rams revealed significant decrease when compared with values of the young rams. Besides, significant reduction was observed in young and elder rams of diseased animals when compared with healthy animals. Nhien et al. (2006) found a significant positive correlation between the serum levels of $\mathrm{Zn} \& \mathrm{Fe}$ and hemoglobin concentration. Since, $\mathrm{Zn}$ and iron deficiency impairs hemoglobin synthesis as in case of Fe-deficiency anemia. Moreover, WHO, (2001) stated in anemic condition, there was lowering in iron serum iron concentrations, low red cell indices, and transferring saturation.

Calcium values of diseased female sheep showed significant decrease in lamb, pregnant ewe and lactating ewe when compared with healthy lamb, pregnant ewe and lactating ewe. Level of the calcium recorded significant decrease in elder rams in comparison with young rams of the healthy and diseased animals. Also, diseased rams showed significant decrease in calcium level of young and elder rams when compared with healthy rams.

Phosphorus level was significantly decreased in the diseased pregnant and elder ewes when compared with those of the healthy animals. Phosphorus level of elder rams revealed significant decrease in diseased animals when compared with healthy elder rams. Magnesium level detected significant changes in diseased lamb, pregnant, lactating and elder ewe when compared with those of healthy animals. Magnesium value of the elder rams of the diseased animals showed significant decrease when compared with that of younger aged rams. The diseased rams showed significant decrease in magnesium level in young and elder animals when compared with healthy rams. Dakka and Abdel all, (1992) noted that calcium and phosphate deficiencies cause many metabolic diseases. Sathis Kumar, (2003) displayed that Ca: P ratio alteration may block action on pituitary gland. This was results in impairing absorption of 
phosphorus, manganese, zinc, copper and other elements from gastro intestinal tract. Ratio $(\mathrm{Ca}: \mathrm{P})$ between 1.5:1 and 2.5:1 for lactating cows should not result in problems.

\section{ACKNOWLEDGEMENTS}

This work was funded through small scale grant from the South Valley University Higher studies and scientific research sector.

We appreciate from all members of Animal Medicine Department, Faculty of Veterinary Medicine, South Valley University, Qena, Egypt for their support and help.

\section{REFERENCES}

Abd El-Raof, Y.M. and Ghanem, M.M. (2006): Clinical and Haemato-Biochemical Studies on Cases of Alopecia in Sheep Due to Deficiency of Some Trace Elements. SCVMJ, X (1): 1726.

Ali, A.A. (2000): Influence of some disease conditions on blood serum levels of antioxidant vitamins and some trace elements of Egyptian Balady sheep in Assiut Governorate. Assiut Vet. Med. J., 42 (84): 120-133.

Bauer, J.D. (1984): Hemoglobin, porphyrin, and iron metabolism. In: Kaplan, LA., Pesce A J., Ed. Clinical Chemistry, theory, analysis and correlation, St. Louis: Mosby Company: 611655.

Borenstein, M.; Rothstein, H. and Cohen, J. (1997): Sample Power Statistics 1.0.SPSS, Inc., Chicago.

Chandra, R.K. (2003): Nutrition and immune system: An introduction. Am. J. Clin. Nutr., 66: 460S463S.

Church, D.C. and Pond, W.G. (1988): Basic animal nutrition and feeding, $3^{\text {rd }}$ Ed. John Wiley and Sons, New York, Chichester, Brisbane, Toronto, Singapore.

Dakka, A.A. and Abdel-All, T.H.S. (1992): Studies on minerals picture in the blood sera of Egyptian sheep. Assiut Vet. Med. Med. J, 28 (55): 242 249.

Dar, A.A.; Jadhav, R.K.; Dimri, U.; Khan, A.A.; Khan, H.M. and Sharma, M.C. (2014): Effects of physiological status and seasonal variation on plasma mineral profile of sheep in Kashmir valley. Scientific Research and Essays, 9 (4): 69-76.

El-Merzabani, M.M.; El-Aaser, A.A. and Zakhary, N.I. (1977): Colorimetric method for determination of phosphorus, J. Clin. Chem. Clin. Biochem., 15: 715-718.

Fahmy, F.; Amer, A.A.; Abd El-Aziz, H. and Abd ElRaof, M. (1980): Wool as an effective tool for diagnosis of some deficiency diseases. Assiut Vet. J., 7: 264-270.

Fieldman, B.F.; Zinkle J.G. and Jain N.C. (2000): Schalm's Veterinary Hematology, $5^{\text {th }}$ edt. Lea and Febiger, Philadelphia, U.S.A.

Ginder, M. and King, J.D. (1972): Rapid colorimetric determination of calcium in biologic fluids with methylthymol blue. Am Clin Path J., 58 (4): 376-82.

Graham, T.W. (1991): Trace element deficiencies in cattle. Vet. Clin. North Am. Food Anim. Pract., 7: 153-215.

Hayakawa, R. (1961): Colorimetric method for determination of zinc, Toxic Environ Health, 18: $14-18$.

Hayat, H.M.; Howeda, M.A. and El-Wakeel, A.S. (2010): Effect of zinc methionine supplementation on reproductive performance, kid's performance, minerals profile and milk quality in early lactating Baladi goats. World ApplSci J., 9: 275-282.

Hayton, B.A.; Broome, H.E. and Lilenbaum, R.C. (1995): Copper deficiency-induced anemia and neutropenia secondary to intestinal malabsorption, American Journal of Hematology, 48 (1): 45-47.

Jones, H.C.; Fontent, J.P. and Veit, H.P. (1990): Physiological and pathological effects of feeding high levels of magnesium to steers. J. Anim. Sci., 68: 4400-4413. PMID: 2286576.

Lucky, Z. (1977): Methods for diagnosis of fish diseases. Amer Publication Co. PVTL td, New Delhi. Bombay, Calcutta and New York.

McDonald, P.; Edwards, R.A. and Greenhalgh, J.F.D. (1984): Animal Nutrition, $3^{\text {rd }}$ Ed. The English Language Book Society.

Nhien, N.V.; Khan, N.C.; Yabutani, T.; Ninh, N.X.; Kkassu, A.; Huong, B.T.M.; Do, T.T.; Motonaka, J. and Ota, F. (2006): Serum Levels of Trace Elements and Iron-Deficiency Anemia in Adult Vietnamese, Biological Trace Element Research, 111: 1-9.

Rink, L. and Ibs, K.H. (2003): Zinc-altered Immune Function. J. Nutr. 133: 204E-205E.

Sahin, T. (1999): Investigation of some trace elements levels and biochemical parameters in sheep with endoparasite. Ph.D. Thesis University YuzuncuYil, Van-Turkey.

Sathish Kumar, (2003): Management of in fertility due to mineral deficiency in dairy animals. In: Proceedings of ICAR summer school on Advance diagnostic techniques and therapeutic approaches to metabolic and therapeutic approaches to metabolic and deficiency diseases in dairy animals. Held at IVRI, Izatnagar, UP. pp. 128-137.

Tashi, N.; Xugang, L.; Shunxiang, Y. and Judson, G. (2005): A survey of the mineral status of livestock in the Tibet Autonomous Region of China. ACIAR working Paper No. 59. 
Teitz, N.W. (1983): Clinical Guide to Laboratory Tests. W. B. Saunders Co. (1983).

Ventura, S. and King, E.J. (1951): Colorimetric method for determination of copper, Biochem J., 48.

Wikse, E.; Field, R. and Holand, P. (1992): Diagnosis of copper deficiency in cattle, JAVMA, 100 (1): 1625-1629.
World Health Organization, WHO (2001): Iron Deficiency Anemia: Assessment, Prevention, and Control-A Guide for Program Managers, World Health Organization, Geneva, Switzerland, 2001.

\section{تقدير لبعض العناصر الصغيرة فى الأغنام السليمة والمريضة فى محافظة قنا \\ ملك اسعاعيل ابراهيم حامد ، عادل السبي أحمد الدكتور ، الصغير عمران أحدد ، حسن بيسف عبد الحمبي}

Email: adel.mohamed@vet.svu.edu.eg Assiut University web-site: www.aun.edu.eg

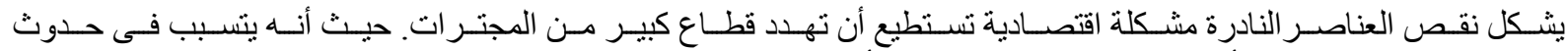

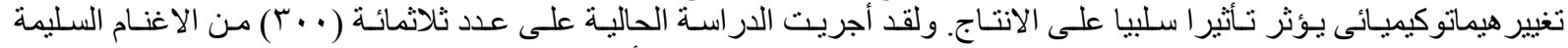

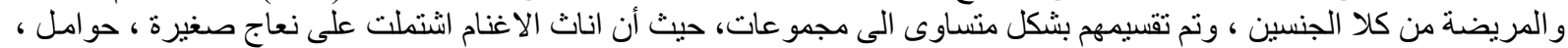

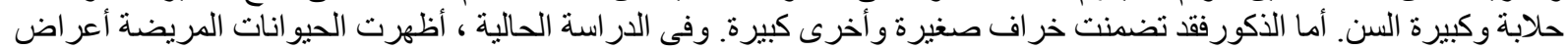

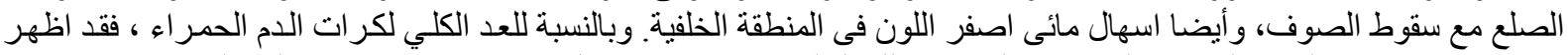

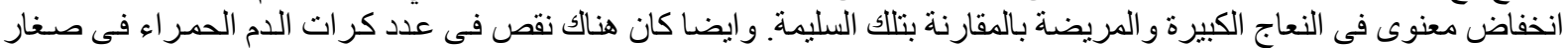

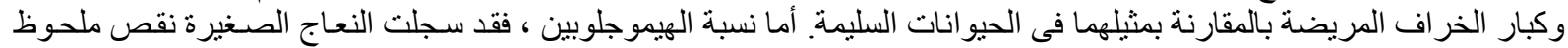

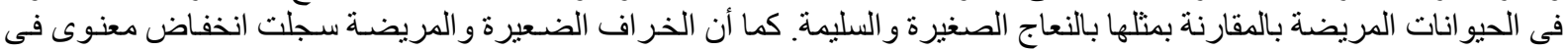

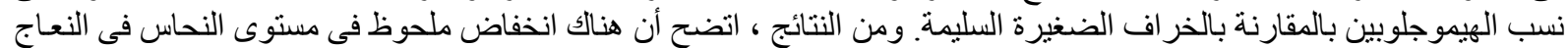

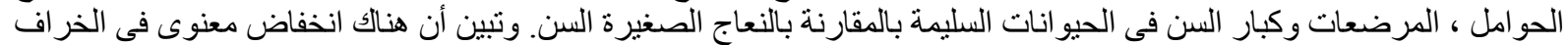

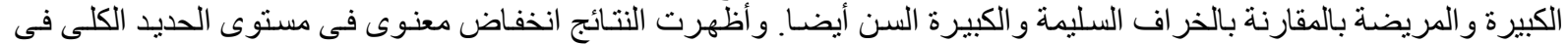

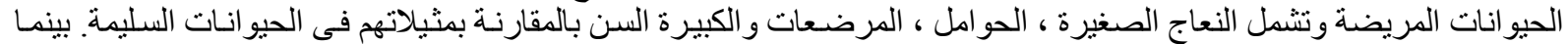

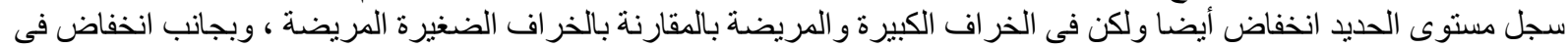

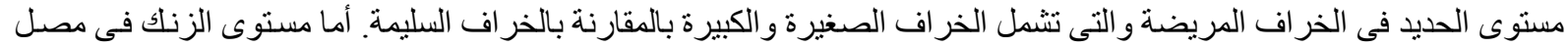

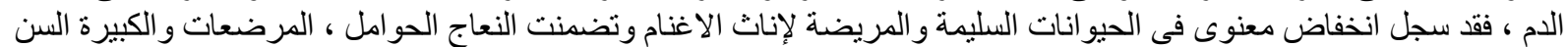

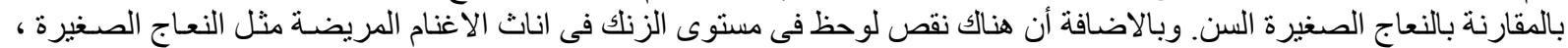

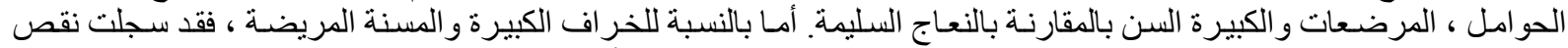

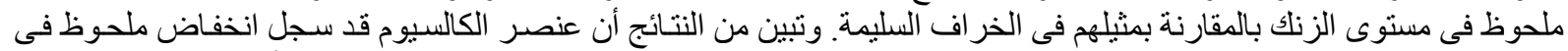

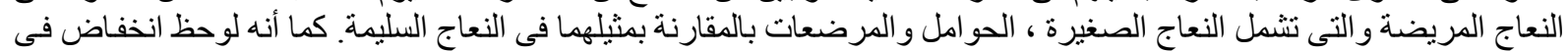

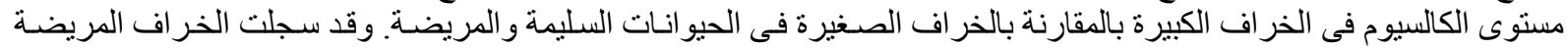

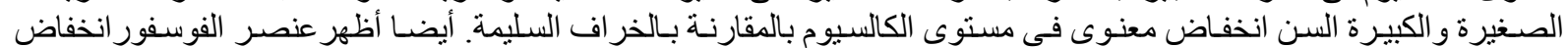

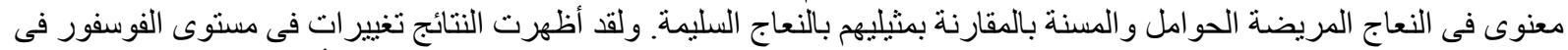

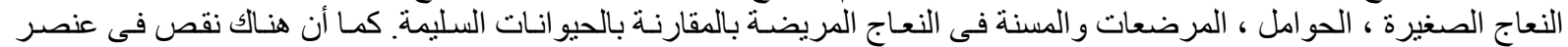

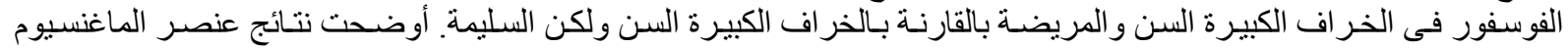

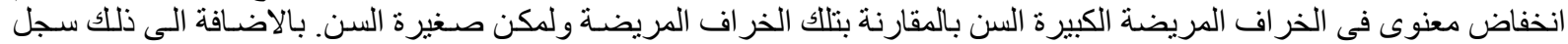
عنصر الماغنسيوم انخفاض معنوى فى الخر اف الصغيرة والكبيرة السن و المريضة بالقارنة بالخر اف السليمة. 